\title{
АМФИФИЛЬНОЕ ПРОИЗВОДНОЕ ТРИФЕНИЛФОСФОНИЯ С ЭТИЛЕНГЛИКОЛЕВЫМ СПЕЙСЕРОМ КАК КОМПОНЕНТ НАПРАВЛЕННЫХ НА МИТОХОНДРИИ СИСТЕМ ДОСТАВКИ ЛЕКАРСТВ
}

\author{
А.П. Садиков, М.А. Варга, У.А. Буданова, Ю.Л. Себякин \\ Институт тонких химических технологий имени М.В. Ломоносова, \\ МИРЭА - Российский Технологический Университет, \\ 119571, Россия, Москва, пр-т Вернадского, д. 86.
}

DOI: 10.19163/MedChemRussia2021-2021-507

E-mail: sadikov.a.p@edu.mirea.ru

Существует ряд заболеваний, связанных с митохондриальной дисфункцией, например ишемические болезни, нейродегенеративные нарушения, рак, диабет. Однако прохождение веществ через мембрану митохондрий затруднена. В связи с этим разработка систем доставки лекарств в эти органеллы является актуальной задачей [1].

Производные трифенилфосфония - это делокализованные липофильные катионы, обладающие способностью накапливаться и проходитьчерез отрицательно заряженныемембраны митохондрий. Недавние исследования invivo [2] показали эффективность алифатических производных трифенилфосфония в борьбе с меланомой.

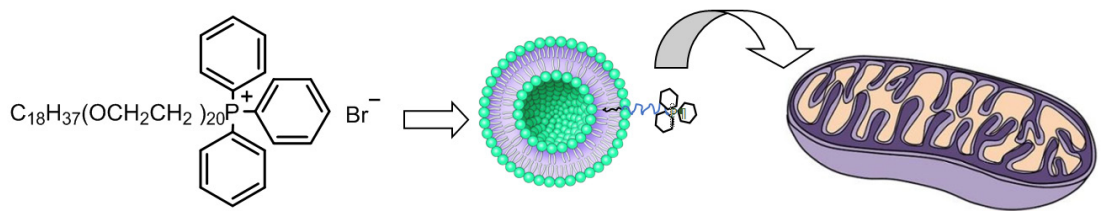

В ходе нашего исследования разработана схема синтеза и осуществлено получение октадецилполиэтиленгликолевого производного трифенилфосфониевой соли. Гидрофобная алкильная цепь позволяет соединению встраиваться в бислой в липосомальной системы доставки лекарств, полиэтиленгликолевый спейсер служит для облегчения взаимодействия векторас поверхностью мишени.

Работа поддержана Российским фондом фундаментальных исследований, грант РФФИ № 19-04-00775.

\section{Литература}

[1] H. Cho, Y.Y.Cho, M.S. Shim, J.Y. Lee, H.S. Lee, H.C. Kang. Biochim Biophys Acta Mol Basis Dis. 2020, 1866 (8), 165808.

[2] K.C. Kloepping, A.S. Kraus, D.K. Hedlund, et al. Triphenylphosphonium derivatives disrupt metabolism and inhibit melanoma growth in vivo when delivered via a thermosensitive hydrogel. PLoS One. 2020 30;15(12): e0244540.

$$
-507-
$$

